\title{
Economic Evaluation of Boceprevir for the Treatment of Patients with Genotype 1 Chronic Hepatitis C Virus Infection in Hungary
}

\author{
Raymond Odhiambo', Jagpreet Chhatwal ${ }^{2}$, Shannon Allen Ferrante ${ }^{3}$, Antoine E1 \\ Khoury $^{3}$, Elamin Elbasha ${ }^{3}$ \\ ${ }^{1}$ MSD Pharma Hungary Kft., Hungary \\ ${ }^{2}$ Graduate School of Publid Health, University of Pittsburgh, Pittsburgh, PA, USA \\ ${ }^{3}$ Merck Sharp \& Dohme Corp., Whitehouse Station, NJ, USA \\ Corresponding author: raymond.odhiambo@merck.com
}

\begin{abstract}
Background: Recent international, randomized, placebo-controlled clinical trials (SPRINT-2; RESPOND-2) demonstrated that the triple combination of peginterferon (PEG), ribavirin (RBV) and boceprevir (BOC) was more efficacious than the standard dual therapy of PEG and RBV in treatment of patients chronically infected with genotype 1 hepatitis $\mathrm{C}$ virus (HCV) infection. The objective of this study was to evaluate the cost-effectiveness of triple therapy in both treatment-naive and treatment-experienced patients in Hungary.
\end{abstract}

Methods: A Markov model was developed to evaluate the long-term clinical benefits and the cost-effectiveness of the triple therapy from the Hungarian payer perspective. Model states were fibrosis (F0-F4, defined using METAVIR fibrosis scores), decompensated cirrhosis (DC), hepatocellular carcinoma (HCC), liver transplantation (LT), and liver-related deaths (LD). Efficacy was estimated from SPRINT-2 and RESPOND-2 studies. Disease progression rates and health state utilities used in the model were obtained from published studies. Estimates of probability of liver transplantation and cost were based on an analysis of the Hungarian Sick Fund database. All cost and benefits were discounted at 5\% per year.

Results: Compared to dual therapy, triple therapy was projected to increase the life expectancy by 0.98 and 2.42 life years and increase the quality-adjusted life years (QALY) by 0.59 and 1.13 in treatment-naive and treatmentexperienced patients, respectively. The corresponding incremental cost-effectiveness ratios were HUF7,747,962 $(€ 26,717)$ and HUF5,888,240 (€20,304) per QALY. The lifetime incidence of severe liver disease events (DC, HCC, LT, LD) were projected to decrease by $45 \%$ and $61 \%$ in treatment-naive and treatment-experienced patients treated with triple therapy groups in comparison with PEG-RBV treatment.

Conclusion: The addition of boceprevir to standard therapy for the treatment of patients with genotype 1 chronic HCV infection in Hungary is projected to be cost-effective using a commonly used willingness to pay threshold of HUF 8.46 million (3 times gross domestic product per capita).

Keywords: chronic hepatitis C; boceprevir, cost-effectiveness, Markov model, peginterferon, ribavirin 


\section{BACKGROUND}

Chronic hepatitis $\mathrm{C}$ virus (HCV) infection is a leading cause of chronic liver disease, liver related deaths, hepatocellular carcinoma (HCC); and the most common indication for liver transplantation. ${ }^{1,2}$ According to the World Health Organization (WHO), about 130-170 million individuals are infected with chronic HCV infection worldwide. ${ }^{3}$ The burden of HCV is substantial, and the cost of treating HCV infection varies from one country to another. ${ }^{4,5}$ In the past decade, awareness about HCV infection has grown among international organizations (e.g. the 'World Hepatitis Day's supported by WHO, European Council), professional organizations, patient organizations, lay press, and governments. In addition, in 2007 hepatitis C has been declared by European Parliament as an urgent public health issue. In Europe, 12 million people are estimated to be living with HCV infection. ${ }^{7}$

The prevalence of HCV infection in Hungary is 0.6 to $0.7 \%$, which corresponds to approximately 60,000 to $70,000 \mathrm{HCV}$-infected persons. ${ }^{8}$ Of the six major HCV genotypes, genotype 1 is the most prevalent $(98 \%$ in Hungary) and the most difficult to treat. ${ }^{8}$ Among patients with chronic HCV infection, at least $20 \%$ develop cirrhosis over a period of 20-25 years. ${ }^{9}$ The risk of developing end-stage liver disease and/or HCC is also high in these patients. In Hungary, infection with HCV is a major public health problem. Diagnosing, treatment and care of advanced liver disease, as well as liver transplantation represent a challenge for both physicians and society. ${ }^{10,11}$ Blood donors have been screened for presence of HCV antibodies since $1992 .{ }^{11}$ The majority of current patients were infected by blood transfusion given before 1992. However, introducing screening for blood donors has been shifting the source of new patients derived from high risk populations such as healthcare workers, people with tattoo, piercing and intravenous drug users. ${ }^{12}$

Currently, no vaccine against $\mathrm{HCV}$ is available; therefore, effective treatment plays an important role in reducing the burden of the disease. The main objective of HCV therapy is to make the virus undetectable for at least 6 months after the treatment ends, which is known as sustained virology response (SVR). The current standard of care (SOC) for management of HCV infection in patients with chronic liver disease is the combination of pegylated interferon and ribavirin (PEG-IFN/RBV). ${ }^{10}$ The efficacy of dual therapy depends on many factors such as genotype, viral load, race, age, fibrosis score and prior treatment. ${ }^{13-17}$ Other factor such as obesity may be predictor for decreased efficacy of dual therapy. ${ }^{18-20}$ The efficacy of the dual combination therapy is about $40 \%$ in treatment naive, genotype 1 patients, and only $22 \%$ in treatment-experienced genotype 1 patients. ${ }^{21,22}$

The addition of boceprevir, a new serine protease inhibitor launched in $2011,^{23}$ to combination of PEG-IFN/ RBV has shown to significantly increase the SVR rates in the treatment of patients with chronic HCV genotype 1. The Serine Protease Inhibitor Therapy 2 (SPRINT-2) and Retreatment with Serine Protease Inhibitor Boceprevir and PegIntron/Rebetol 2 (RESPOND-2) clinical trials ${ }^{24,25}$ demonstrated that the SVR rate achieved by adding boceprevir to PEG-IFN/RBV is $67-68 \%$ vs. $40 \%$ in treatment-naive patients and $59-66 \%$ vs. $21 \%$ in treatment-experienced patients.

\section{Objective}

The objective of this study was to project the long-term clinical benefits of the addition of boceprevir (registered by the European Medicines Agency [EMA] in July 201126) to the current standard of care, and estimate its costeffectiveness in comparison with standard of care in patients with genotype $1 \mathrm{HCV}$-infection in Hungary. 


\section{METHODS}

A decision analytic model was developed to simulate boceprevir-based treatment strategies as approved by EMA and the standard dual therapy. Patients who were not cured progressed to the natural history component of chronic HCV infection, which was modeled as a multi-cohort Markov state-transition model (Figure 1). The model projected the incidence of advanced liver disease (decompensated cirrhosis [DC]), HCC and liver transplantation over lifetime. The structure of the model is similar to other published models for HCV. ${ }^{27-30}$ The model estimates the health outcomes and costs of different treatment strategies over lifetime horizon in patient cohorts representative of HCV population in Hungary (Table 1).

Figure 1. State-transition Diagram for the Markov Model

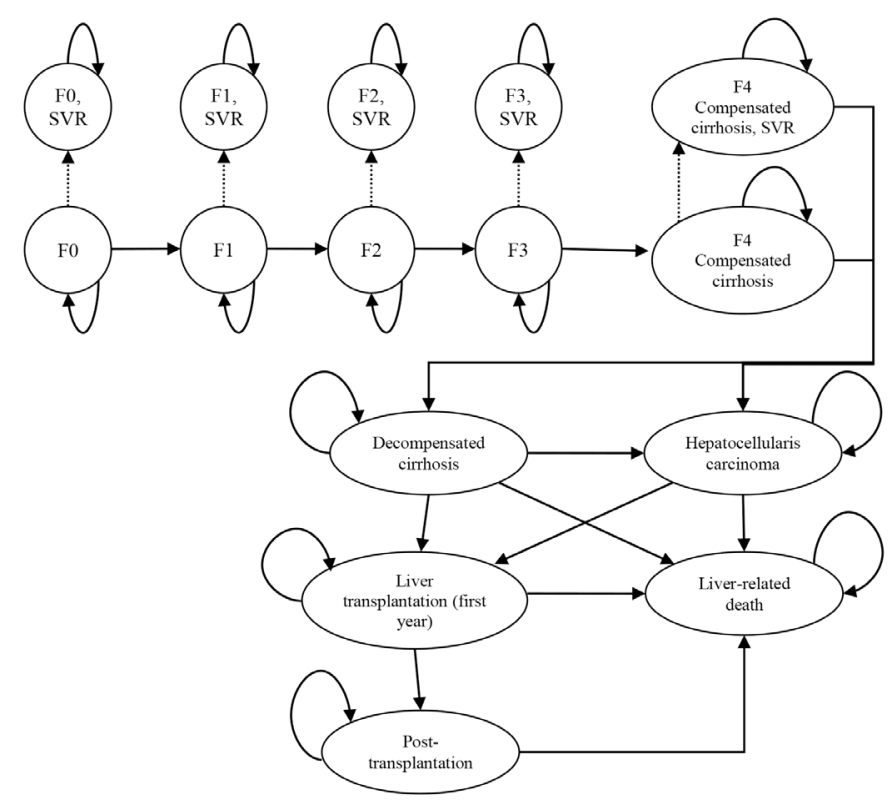

$\mathrm{SVR}=$ sustained viral response

Table 1. Characteristics of Patients in the Model

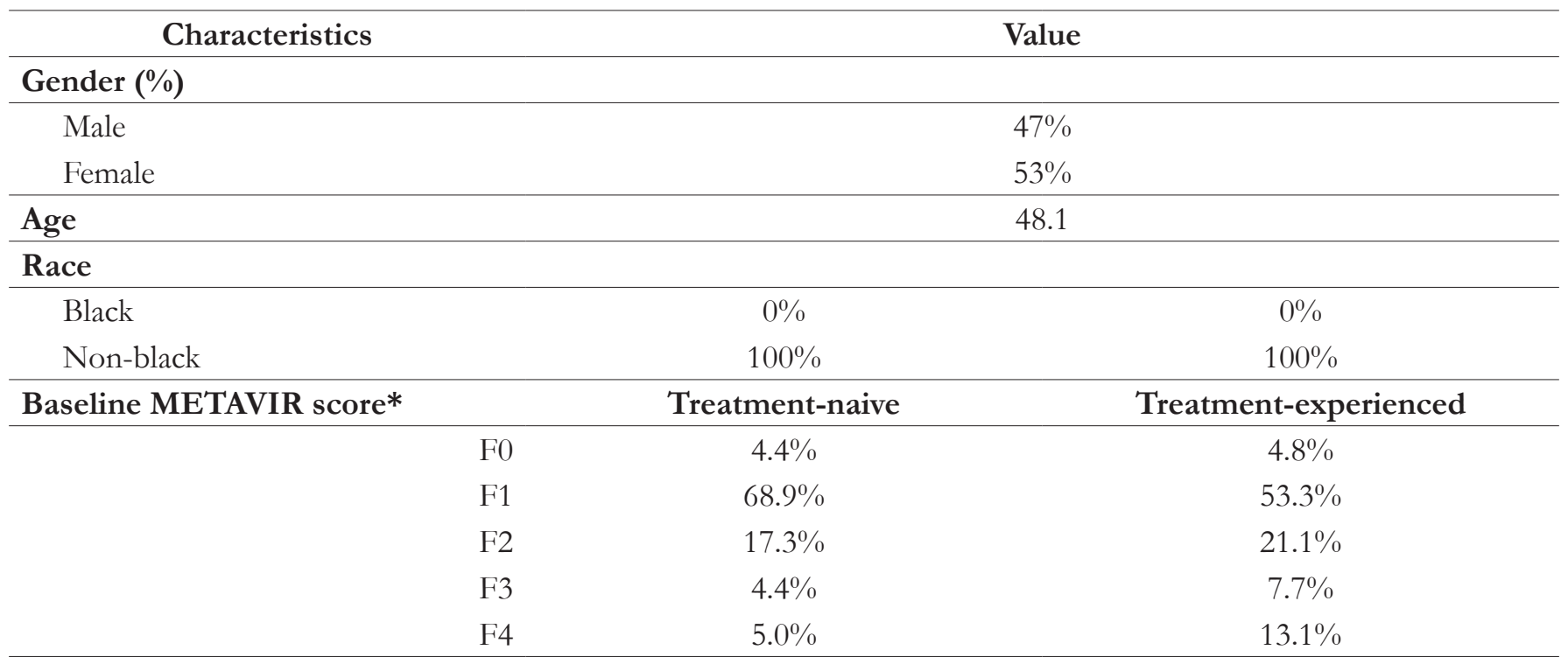

*derived from clinical trials 


\section{Treatment Strategies and Duration}

The EMA approved treatment strategies differ according to baseline fibrosis score and prior treatment experience. Separate analyses were conducted for treatment-naive and treatment-experienced patients, with and without cirrhosis.

All patients whether they are treatment-naïve or treatment-experienced, receive PEG-INF/RBV combination therapy during the initial 4-week 'lead-in' period. Subsequently, all patients assigned to control arm are administered 44 weeks of PEG-INF/RBV.

In the 'Boceprevir' (BOC)-arm, the baseline fibrosis score (and response in case of non-cirrhotic, treatmentnaïve patients) determines that whether patients receive 24, 32 or 44-week triple combination therapy (PEF$\mathrm{INF} / \mathrm{RBV} / \mathrm{BOC}$ ) after the 4-week 'lead-in'. Both treatment-naïve and treatment-experienced patients who receive 32-week triple combination therapy after initial 'lead-in' period, are administered additional PEG-INF/ RBV up to week 48 (Figure 2 and 3).

Figure 2. Treatment Strategies in the Model (Treatment-naive Patients)

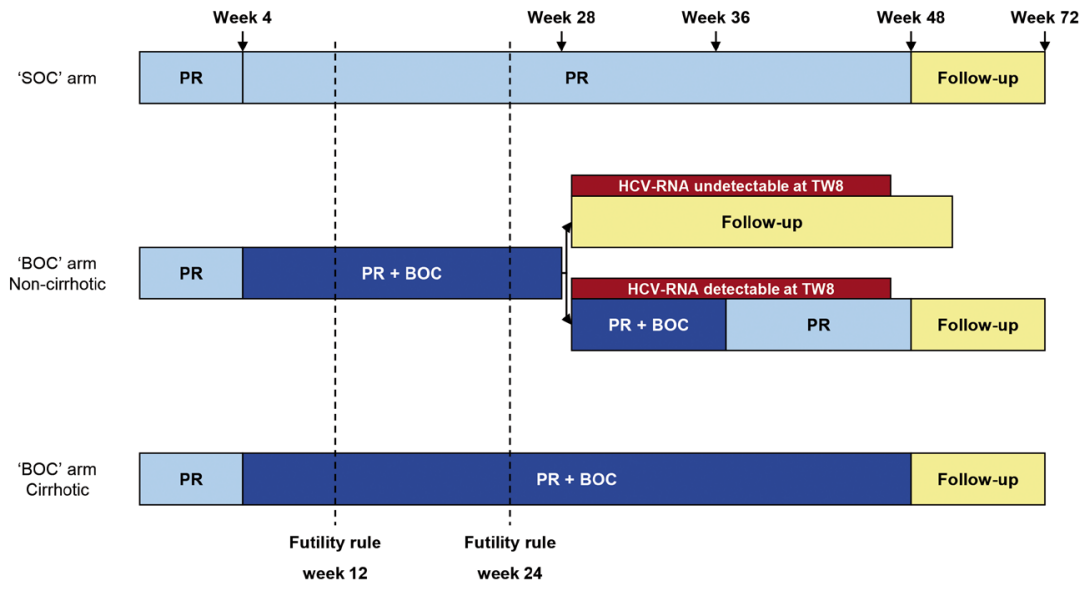

$\mathrm{SOC}=$ standard of care (pegylated interferon and ribavirin); BOC=pegylated interferon and ribavirin plus boceprevir; HCVRNA=hepatitis $\mathrm{C}$ virus ribonucleic acid; TW-treatment week

Figure 3. Treatment Strategies in the Model (Treatment-experienced Patients)

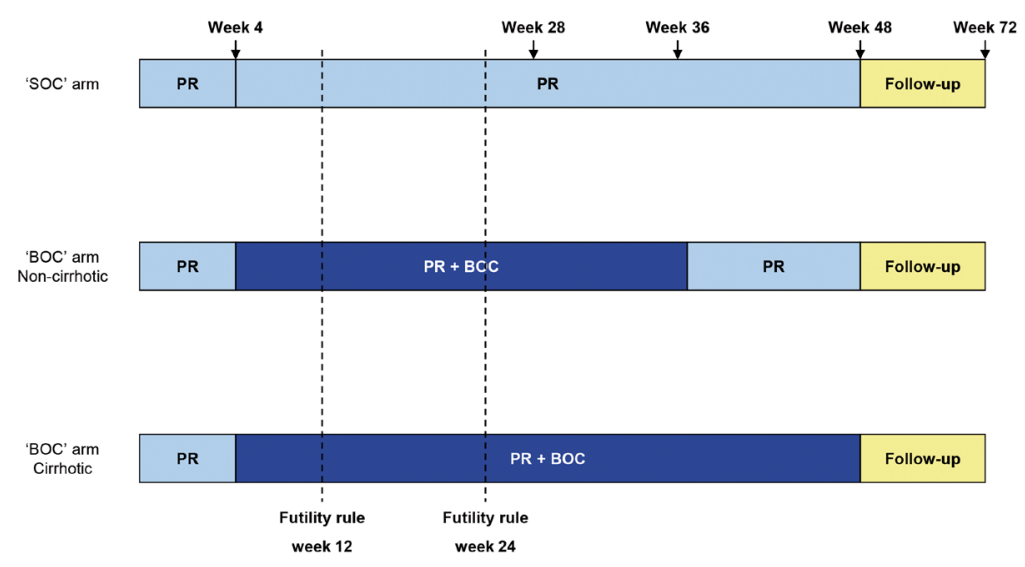

$\mathrm{SOC}=$ standard of care (pegylated interferon and ribavirin); $\mathrm{BOC}=$ pegylated interferon and ribavirin plus boceprevir; 


\section{Model Structure}

For patients who are not cured by treatment, the model simulates the natural course of chronic HCV infection and projects the incidence of advanced liver disease(s) (DC, HCC), and liver transplantation and liver-related deaths over lifetime. The model takes into account a number of health conditions including the severity of chronic HCV infection, which was measured in the trials by the degree of fibrosis using METAVIR scoring system: no fibrosis (F0), portal fibrosis without septa (F1), portal fibrosis with few septa (F2), numerous septa without fibrosis (F3) and compensated cirrhosis (F4). The model assumes that a patient with a given fibrosis score may progress to more severe stages of liver disease, or may remain in that given health state. Patients with compensated cirrhosis are at risk for developing DC and/or HCC. For patients with DC and/or HCC, liver transplantation may be performed. Due to differences in mortality and interventions between periods immediately following transplantation and the following years, liver-transplant state is divided into two stages: "liver transplantation", which lasts for one year, and "Post-liver transplant" state to which a transition is made if a patient is alive at the end of the first year. Patients with DC, HCC, and liver transplantation are at higher risk of mortality compared with the general population. All other patients face the same mortality risk as the general population. We used Excel 2003 (Microsoft Corp., Redmond, Washington) to build the model and to do all calculations.

\section{Clinical Data}

Sustained virological response data as a measure of effectiveness of antiviral therapy were derived from the multicenter, placebo-controlled trials (SPRINT-2 ${ }^{24}$, RESPOND-2 ${ }^{25}$ ) (Table 2 and Table 3). The target population was patients with genotype 1 chronic HCV infection with or without prior HCV treatment experience. Patient characteristics impact the effectiveness of treatment regimens, the rate of disease progression in patients who do not achieve SVR, and the annual mortality rate. Though SVR rates in SPRINT-2 study were evaluated separately for black and non-black patients, we did not include race in our model because ethnicity along with nationality, mother tongue, religion, chronic illness and disability are regarded as sensitive questions according the Hungarian Population Census. The response to these questions is voluntary. ${ }^{31}$ Therefore, no explicit data are available on racial background (black or non-black as defined in the clinical trials ${ }^{24,25}$ ) in either the total population or HCV-infected population in Hungary. However, it can be inferred from the retrospective analysis of the National Central Statistical Office's database shows that out of "Persons naturalized in Hungary" and "Foreign citizens reside in Hungary" 32 less than $0.5 \%$ of total population has (previous) citizenship in a country out of Europe and North America. This also suggests that Hungarian population is mostly white. Therefore, only non-black population was analysed in the non-cirrhotic treatment-naive population.

The clinical trials used METAVIR scoring system to define the severity of hepatitis C disease; however, reporting of fibrosis scores is not mandatory in several cases in Hungary. ${ }^{8}$ Since reliable data are not available on the distribution of fibrosis scores in Hungary, we used the distribution of patients' METAVIR scores from the clinical trials. ${ }^{24,25}$ To define the average age of patient cohort in the analysis a market research was carried out by an external pharmaceutical market research agency in April 2011. Two hundred twenty patient-reports from 20 centers (out of $30^{33}$ ) were involved. Only the reports of patients with finished treatment were included the analysis. The sample was representative of the Hungarian HCV population and included $47 \%$ of male and $53 \%$ of female patients. The analysis showed that the average age of patients with HCV infection treated is 48.1 years. 
Table 2. Treatment Outcomes in Treatment-naive Patients

\begin{tabular}{|c|c|c|}
\hline & \multicolumn{2}{|c|}{ Non-cirrhotic* } \\
\hline & SOC & BOC \\
\hline$\%$ experience anemia & $26.3 \%$ & $48.1 \%$ \\
\hline$\%$ receive erythropoietin $(\mathrm{EPO}) /$ anemia & $75.3 \%$ & $85.2 \%$ \\
\hline Mean duration of anemia (days) & 104.5 & 88.5 \\
\hline Mean duartion of EPO use (days) & 104.9 & 87.5 \\
\hline$\%$ fail futility rule at wk12 & $42.3 \%$ & $7.1 \%$ \\
\hline$\%$ fail futility rule at wk 24 & $9.8 \%$ & $11.2 \%$ \\
\hline \multirow[t]{3}{*}{$\% \mathrm{SVR} * * *$} & $36.6 \%$ & $68.2 \%$ \\
\hline & \multicolumn{2}{|c|}{ Cirrhotic** } \\
\hline & SOC & BOC \\
\hline$\%$ experience anemia* & $23.1 \%$ & $54.2 \%$ \\
\hline$\%$ receive erythropoietin (EPO)/anemia* & $100 \%$ & $92.3 \%$ \\
\hline Mean duration of anemia (days)* & 113.3 & 89.8 \\
\hline Mean duartion of EPO use (days)* & 236 & 152.8 \\
\hline$\%$ fail futility rule at wk12 & $46.2 \%$ & $21.7 \%$ \\
\hline$\%$ fail futility rule at wk24 & $14.3 \%$ & $22.2 \%$ \\
\hline$\% \mathrm{SVR} * *$ & $38.5 \%$ & $41.7 \%$ \\
\hline
\end{tabular}

*only non-black ** cirrhotic: entire cohort of both black and non-black ***based on EMA label

$\mathrm{SOC}=$ standard of care (peginterferon alfa+ribavirin); BOC $=$ peginterferon alfa + ribavirin + boceprevir; $\mathrm{SVR}=$ sustained viral response; $\mathrm{EPO}=$ erythropoietin

Table 3. Treatment Outcomes in the Treatment-experienced Patients

\begin{tabular}{lcc}
\hline & \multicolumn{2}{c}{ Non-cirrhotic } \\
\hline \% experience anemia & SOC & BOC \\
\% receive erythropoietin (EPO)/anemia & $19.7 \%$ & $40.9 \%$ \\
Mean duartion of anemia (days) & $100 \%$ & $98.4 \%$ \\
Mean duartion of EPO use (days) & 75.0 & 132.7 \\
\% fail futility rule at wk12 & 66.1 & 137.4 \\
\% fail futility rule at wk24 & $46.9 \%$ & $9.0 \%$ \\
\% SVR* & $28.1 \%$ & $13.2 \%$ \\
\hline & $24.2 \%$ & $64.4 \%$ \\
\hline \% experience anemia & & \\
\% receive erythropoietin (EPO)/anemia & SOC & BOC \\
Mean duartion of anemia (days) & $19.7 \%$ & $46.7 \%$ \\
Mean duartion of EPO use (days) & $100 \%$ & $100 \%$ \\
\% fail futility rule at wk12 & 75.0 & 132.7 \\
\% fail futility rule at wk24 & 66.1 & 131.9 \\
\% SVR* & $77.8 \%$ & $4.8 \%$ \\
\hline
\end{tabular}

*based on EMA label; SOC=peginterferon alfa + ribavirin; $\mathrm{BOC}=$ peginterferon alfa + ribavirin + boceprevir; SVR $=$ sustained viral response; $\mathrm{EPO}=$ erythropoietin 
The progression rates describing natural course of chronic HCV infection were derived from Thein et al. study. ${ }^{34}$ The baseline likelihood of developing HCC in patients with F3 state was estimated from Yoshida et al. ${ }^{35}$ a retrospective cohort study. ${ }^{36,37}$ Annual incidence of HCC increases with development of cirrhosis. An excess risk of HCC and DC from compensated cirrhosis was estimated from Fattovich et al., ${ }^{38}$ long-term follow-up study. ${ }^{39-44}$ The probability of liver transplantation in advanced stages and mortality rates were derived from the National Health Insurance Fund's database research and analysis, the National Central Office of Statistics and other published data (Table 4)..$^{38,45-50}$

Table 4. Annual Transition Probabilities

\begin{tabular}{|c|c|c|c|}
\hline Parameter & Baseline & Range & Source \\
\hline \multicolumn{4}{|l|}{ Fibrosis progression } \\
\hline F0 to F1 & 0.117 & $0.104-0.130$ & 34 \\
\hline $\mathrm{F} 1$ to $\mathrm{F} 2$ & 0.085 & $0.075-0.096$ & 34 \\
\hline $\mathrm{F} 2$ to $\mathrm{F} 3$ & 0.120 & $0.109-0.133$ & 34 \\
\hline $\mathrm{F} 3$ to $\mathrm{F} 4$ & 0.116 & $0.104-0.129$ & 34 \\
\hline \multicolumn{4}{|l|}{ Fibrosis 3} \\
\hline To HCC* & 0.0095 & $0.00-0.0144$ & $35,36,37$ \\
\hline \multicolumn{4}{|l|}{ Compensated cirrhosis } \\
\hline To DC & 0.029 & $0.010-0.039$ & $35,36,38,39,40,41,42$ \\
\hline To HCC & 0.028 & $0.010-0.079$ & $35,36,38,39,40,41,42,43,44$ \\
\hline \multicolumn{4}{|l|}{ DC } \\
\hline To HCC & 0.068 & $0.030-0.083$ & 45 \\
\hline \multicolumn{4}{|c|}{ Probability of liver transplantation } \\
\hline In DC & 0.016 & 0.016 & 46 \\
\hline In HCC & 0.0083 & 0.0083 & 46 \\
\hline \multicolumn{4}{|l|}{ Mortality } \\
\hline Death (all-cause) & Gender- and age specific & & 47 \\
\hline \multicolumn{4}{|l|}{ Liver-related mortality } \\
\hline DC (first year) & 0.182 & $0.065-0.190$ & 45 \\
\hline DC (subsequent years) & 0.112 & $0.065-0.190$ & 45 \\
\hline $\mathrm{HCC}$ & 0.427 & $0.330-0.860$ & 38 \\
\hline \multicolumn{4}{|l|}{ Liver-transplantation } \\
\hline (first year) & 0.166 & $0.060-0.420$ & 48 \\
\hline \multicolumn{4}{|l|}{ Liver-transplantation } \\
\hline (subsequent years) & 0.044 & $0.024-0.110$ & 48 \\
\hline
\end{tabular}

DC: decompensated cirrhosis; HCC: hepatocellular carcinoma

* Calculated by using Yoshida $1999{ }^{35}$

\section{Health Care Costs and Quality of Life Data}

The utility weights associated with health states, treatment and adverse events were obtained from published studies (Table 5). ${ }^{51-54}$ The baseline utility weight for the general population was set equal to 1 . All health-state utility weights, obtained from Chong et al. were normalized to the utility weights of general population. Since anemia was a major adverse event associated with boceprevir-based treatment, we also included the disutility of anemia in the model. 
The analysis was conducted from payer's perspective. In Hungary, health services are primarily funded by the state-owned National Health Insurance Fund Administration (NHIFA). The public health services delivered by state- or local government-owned public providers or private players, both contracted with the NHIFA, are registered in the financing database of NHIFA. ${ }^{55}$ The cost input data representing real-life resource utilization is based on publicly accessed NHIFA's reports and the results of NHIFA's database research and analyses, as well as using micro-costing methods. Researchers cannot have direct access to the NHIFA's database; however, NHIFA has a regulated service that provides statistical data. A research design was developed involving two researchers and a leading physician in HCV treatment. Both the design and the results of the analyses were validated by two medical experts.

Table 5. Parameters of Utility

\begin{tabular}{lll}
\hline \multicolumn{1}{c}{ Parameter } & Baseline & Source \\
\hline Utility weights for general population & 1 & \\
\hline Antiviral (AV) drug therapy-related utility weights & & 52 \\
\hline PEG-RBV (no side effects) & $(1-0.15)^{*} \mathrm{U}_{\mathrm{F}}$ & 52 \\
PEG-RBV-BOC (no side effects) & $(1-0.15)^{*} \mathrm{U}_{\mathrm{F}}$ & 53 \\
AV-related anemia & $(1-0.17)^{*} \mathrm{U}_{\mathrm{F}}$ & 54 \\
\hline Post-treatment & & 52 \\
\hline 'End of Treatment' response & $\mathrm{U}_{\mathrm{F}} / 0.95$ & \\
Sustained Virological Response (Cured) & $1.12 * \mathrm{U}_{\mathrm{F}}$ & 51 \\
\hline Health state utility weights & & 51 \\
\hline F0 & 0.78 & 51 \\
F1 & 0.78 & 51 \\
F2 & 0.78 & \\
F3 & 0.78 & 51 \\
Compensated cirrhosis & 0.78 & 51 \\
DC (first year) & 0.74 & 51 \\
DC (subsequent years) & 0.74 & 51 \\
HCC (first year) & 0.55 & 51 \\
HCC (subesquent years) & 0.55 & 51 \\
Liver transplantation (first year) & 0.75 & \\
Liver transplantation (subsequent years) & 0.75 & \\
\hline $\mathrm{U}_{\mathrm{F}}$ - Baseline fibrosis-related utility & & \\
DC: decompensated cirrhosis; HCC: hepatocellular carcinoma & & \\
\hline
\end{tabular}

The cost associated with early stages (F0-F3) of the disease was estimated using micro-costing: real-life resource utilization was collected with questionnaires and unit costs derived from public NHIFA's reports were applied. All costs were converted to 2011 Hungarian Forints (Table 6).

Patients who developed treatment-related anemia in the clinical trials ${ }^{24,25}$ were managed by reduction of ribavirin dose or administration of erythropoetin (EPO). In Hungary, gradual ribavirin dose reduction is recommended as the most efficient option for management of AV therapy-induced anemia. ${ }^{56}$ EPO accessable is neither indicated nor reimbursed in the management of HCV therapy-related anemia in Hungarian setting. Also, a recent study demonstrated that there is no difference in SVR rates achieved in anemic patients receiving boceprevir plus peginterferon-ribavirin using either ribavirin dose reduction or EPO. ${ }^{57}$ 
In line with the Hungarian therapeutical practice, we assumed that all anemia cases are managed by ribavirin dose reduction. Therefore, the cost of anemia management was set to zero at base case; however, different EPO costs were analysed in the sensitivity analysis.

Table 6. Cost Data Used in the Model

\begin{tabular}{lc}
\hline \multicolumn{1}{c}{ Parameter } & Basecase, HUF (€) \\
\hline Antiviral (AV) drug therapy-related costs (weekly) & \\
\hline PEG+RBV & $109,311(€ 377)$ \\
Victrelis (boceprevir) & $232,370(€ 801)$ \\
EPO (anemia) & $110,548(€ 381)$ \\
\hline Monitoring & \\
\hline 'Standard of care' & $111,866(€ 386)$ \\
Three medicine combination & $147,192(€ 508)$ \\
\hline Health state costs (annual) & \\
\hline F0 & $7,268(€ 25)$ \\
F1 & $25,530(€ 88)$ \\
F2 & $25,530(€ 88)$ \\
F3 & $25,530(€ 88)$ \\
Compensated cirrhosis & $304,617(€ 1,050)$ \\
DC (first year) & $905,011(€ 3,121)$ \\
DC (subsequent years) & $677,955(€ 2,338)$ \\
HCC (first year) & $3,498,735(€ 12,065)$ \\
HCC (subsequent years) & $718,943(€ 2,479)$ \\
Liver transplantation (first year) & $18,309,513(€ 63,136)$ \\
Liver transplantation (subsequent years) & $1,827,296(€ 6,301)$ \\
\hline Discount rate & $5 \%$ \\
\hline Time horizon & Life-time \\
\hline *only in sensitivity analysis included; DC=decompensated cirrhosis; HCC=hepatocellular carcinoma; PEG+RBV=peginterferon \\
plus ribavirin
\end{tabular}

The direct medical cost of HCV infection includes the cost of treatment, HCV health state-related costs, and the cost of liver transplantation. QALYs depend on whether or not the patient is cured, and for uncured patients, the progression of disease and the amount of time spent in each of the HCV disease stages. Both costs and QALYs were discounted at 5\%.

\section{Model Outcomes}

We projected the lifetime incidence of complications, total costs, and QALYs associated with each treatment strategy. We also estimated the incremental cost-effectiveness ratios (ICERs) for boceprevir-based regimens compared to treatment with peginterferon and ribavirin. The model estimated the cost-effectiveness of boceprevir-based treatment strategy separately for the treatment-naive and the treatment-experienced patient groups.

There is no official cost-effectiveness threshold in Hungary. Therefore, the WHO-CHOICE ${ }^{58}$ guideline around the cost-effectiveness threshold (3 times of gross domestic product (GDP) per capita) was taken into account when interpreting the results. Based on the 2011 National Central Office of Statistics data, 39 times 
of GDP per capita is 8.46 million Hungarian forint (HUF) $(€ 29,172)$.

\section{Sensitivity Analyses}

To test the robustness of the model results and the impact of varying parameters on costs and QALYs, both deterministic and probabilistic sensitivity analyses (PSA) were performed. Parameters such as age, transition probabilities, treatment effectiveness, quality of life weights, health care costs, discount rates, implication of EPO cost and mortality in health state of compensated cirrhosis were tested over a plausible range. The base case input data and the lower- and upper bounds of ranges are derived from published data when available (Table 4).

In the base case scenario, both costs and health outcomes were discounted at 5\%, as specified in the Hungarian Guideline on preparation health economic analyses. Following the guideline, sensitivity analysis was also performed on the discount rates of costs and health outcomes using the range of 3-6\% and $0-6 \%$, respectively. These guidelines are similar to the recommendations of other European national agencies. ${ }^{61-68}$

\section{RESULTS}

\section{Base-case Analysis}

In treatment-naive patients, the boceprevir-based triple combination therapy was projected to increase the life expectancy by 0.98 years and QALY by 0.59 in comparison to treatment with the dual therapy (Table 7). Boceprevir-based therapy costs HUF 4.56 million (€15,707) more than SOC. In treatment-experienced patients, boceprevir-based therapy was projected to increase the expected life by 2.42 life years and QALYs by 1.13, and cost HUF 6.66 million $(€ 22,972)$ more in comparison to treatment with the dual therapy. Triple therapy resulted in HUF 7,747,962 (€26,717) and HUF 5,888,240 (€20,304) per QALY in the treatment-naive and treatmentexperienced patient groups, respectively (Table 7). The relative risk of severe liver disease-related complications such as DC, HCC, liver-related death was projected to decrease over lifetime both in the treatment-naive and the treatment-experienced patients (Table 8).

Table 7. Results

\begin{tabular}{lcccc}
\hline \multicolumn{1}{c}{ Strategies } & LE & Cost (HUF) & QALY & ICER (HUF/QALY) \\
\hline Treatment-naive patients & \multicolumn{5}{c}{} & \\
\hline SOC & 25.31 & $4,035,025(€ 13,914)$ & 10.96 & \\
BOC & 26.29 & $8,590,334(€ 29,622)$ & 11.55 & $7,747,962(€ 26,717)$ \\
$\Delta$ & 0.98 & $4,555,309$ & 0.59 & \\
\hline Treatment-experienced patients & & & \\
\hline SOC & 23.77 & $4,338,644(€ 14,961)$ & 10.35 & \\
BOC & 26.19 & $11,000,397(€ 37,932)$ & 11.48 & $5,888,240(€ 20,304)$ \\
$\Delta$ & 2.42 & $6,661,753$ & 1.13 & \\
\hline SOC=standard of care (peginterferon plus ribavirin) & & & \\
BOC=boceprevir added to peginterferon plus ribavirin & &
\end{tabular}


Table 8. Projected lifetime incidence of serious liver complications in the treatment naïve and prevously treated patients (per 1000 patients)

\begin{tabular}{|c|c|c|c|c|}
\hline \multirow{2}{*}{ Patients } & \multirow{2}{*}{ Treatment } & \multicolumn{3}{|c|}{ Liver disease- related complications } \\
\hline & & DC** & HCC** & Liver-related death \\
\hline \multirow[t]{3}{*}{ Naive } & SOC* & 100 & 148 & 183 \\
\hline & BOC* & 55 & 80 & 99 \\
\hline & $\%$ reduction $* * *$ & $45 \%$ & $46 \%$ & $46 \%$ \\
\hline \multirow[t]{3}{*}{ Previously treated } & SOC* & 153 & 217 & 277 \\
\hline & BOC* & 59 & 86 & 108 \\
\hline & $\%$ reduction $* * *$ & $61 \%$ & $60 \%$ & $61 \%$ \\
\hline $\begin{array}{l}* \mathrm{SOC}=\text { standard of ca } \\
\mathrm{BOC}=\text { boceprevir add } \\
* * \mathrm{DC}=\text { decompensatec } \\
\text { HCC=hepatocellular c } \\
* * * \% \text { Reduction: } \mathrm{BOC}\end{array}$ & $\begin{array}{l}\text { interferon plus riba } \\
\text { eginterferon plus ri } \\
\text { osis } \\
\text { ma } \\
\text { ared to SOC }\end{array}$ & & & \\
\hline
\end{tabular}

\section{Sensitivity Analyses}

The deterministic sensitivity analysis shows that the model results are sensitive to changes in parameters of efficacy (SVR rates), utilities and transition probabilities (Table 9). The ICER obtained from the model exceeded the cost-effectiveness threshold only when assuming the lower value of transition probabilities or the lower incremental health gain (SVR) achieved by boceprevir.

PSA was conducted using 1,000 Monte Carlo simulations and results were presented using cost-effectiveness scatter plots (Figure 4 and Figure 5). The cost-effectiveness acceptability curve (CEAC) showed that the boceprevir-based regimen was cost-effective with a probability of $63 \%$ and $93 \%$ in treatment-naive and treatment-experienced patients, respectively at a willingness-to-pay value of HUF 8.46 million (Figure 6 and Figure 7). 
Table 9. The Deterministic Sensitivity Analysis Results (ICER; million HUF)

\begin{tabular}{|c|c|c|}
\hline Parameter & $\begin{array}{l}\text { Tx-naïve, } \\
\text { million HUF } \\
\text { ('000€) }\end{array}$ & $\begin{array}{l}\text { Tx-experienced, } \\
\text { million HUF } \\
\text { ('000€) }\end{array}$ \\
\hline Base-case & $7.75(26.7)$ & $5.88(20.3)$ \\
\hline \multicolumn{3}{|l|}{ Age (average age of cohort) } \\
\hline 35 years old & $5.46(18.8)$ & $4.19(14.4)$ \\
\hline 43 years old & $6.69(23.1)$ & $5.09(17.6)$ \\
\hline 53 years old & $9.13(31.5)$ & $6.96(23.9)$ \\
\hline \multicolumn{3}{|l|}{ Probabilities receiving liver transplantation } \\
\hline DC: $0.032 ;$ HCC: 0.016 & $7.73(26.7)$ & $5.85(20.2)$ \\
\hline EPO cost - 110548 HUF & $8.16(28.1)$ & $6.49(22.4)$ \\
\hline \multicolumn{3}{|l|}{ Discount rate } \\
\hline $0 \%$ & $2.51(8.7)$ & $1.85(6.4)$ \\
\hline $3 \%$ & $5.27(18.2)$ & $3.94(13.6)$ \\
\hline Cost: $5 \%$; Outcome: $0 \%$ & $2.92(10.0)$ & $2.19(7.6)$ \\
\hline \multicolumn{3}{|l|}{ Progression after SVR } \\
\hline (DC:0,008; HCC:0,005)* & $7.77(26.8)$ & $6.63(22.8)$ \\
\hline \multicolumn{3}{|l|}{ Transition probabilities } \\
\hline All lower limits & $10.46(36.1)$ & $8.64(29.7)$ \\
\hline All upper limits & $5.72(19.7)$ & $5.03(17.3)$ \\
\hline Compensated cirrhosis $\rightarrow$ Death $(0,0566)^{* *}$ & $6.38(21.9)$ & $4.51(15.5)$ \\
\hline \multicolumn{3}{|l|}{ Health state costs } \\
\hline$-15 \%$ & $7.86(27.1)$ & $6.02(20.7)$ \\
\hline$+15 \%$ & $7.64(26.3)$ & $5.76(19.8)$ \\
\hline \multicolumn{3}{|l|}{ Utilities } \\
\hline All lower limits & $8.59(29.6)$ & $6.47(22.3)$ \\
\hline All upper limits & $5.92(20.4)$ & $4.72(16.2)$ \\
\hline \multicolumn{3}{|l|}{ SVR } \\
\hline Low $95 \%$ for SOC & $5.97(20.6)$ & $5.04(17.4)$ \\
\hline High $95 \%$ for SOC & $11.27(38.8)$ & $9.42(32.5)$ \\
\hline Low $95 \%$ for BOC & $10.51(36.2)$ & $7.72(26.6)$ \\
\hline High 95\% for BOC & $6.07(20.9)$ & $4.70(16.2)$ \\
\hline $\begin{array}{l}\text { SOC: standard of care (peginterferon plus ribavirin) } \\
\text { BOC: triplet therapy (peginterferon -ribavirin plus boceprevir } \\
\text { SVR: sustained virological response } \\
\text { *Source: Cardoso } 201085 \\
\text { **Calculated by using Flaming } 201086\end{array}$ & & \\
\hline
\end{tabular}


Figure 4. The Results of Probabilistic Sensitivity Analysis in Treatment-naive Patients

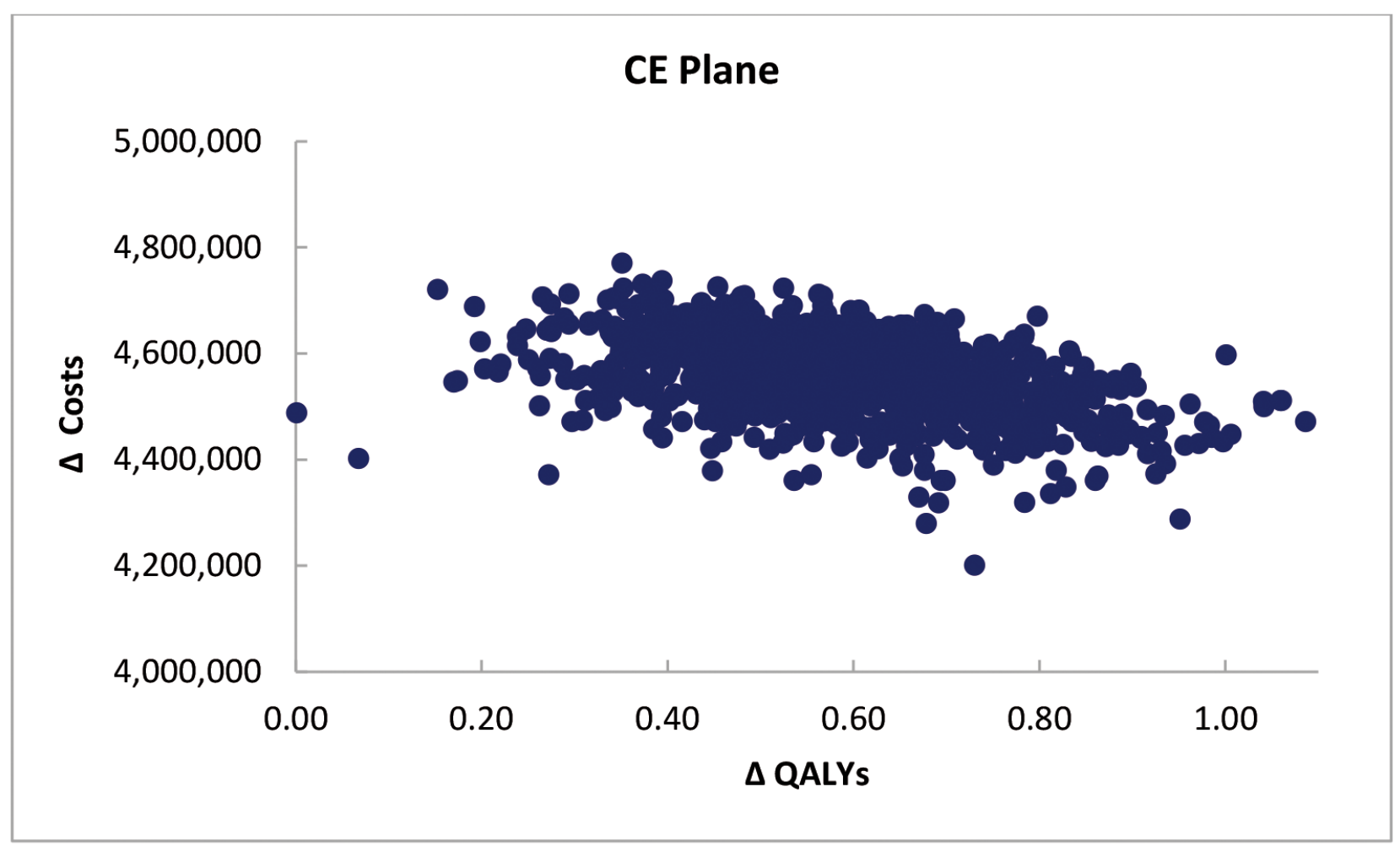

$\mathrm{CE}=$ cost effectiveness; $\mathrm{QALY}=$ quality-adjusted life year

Figure 5. The Results of Probabilistic Sensitivity Analysis in Treatment-experienced Patients

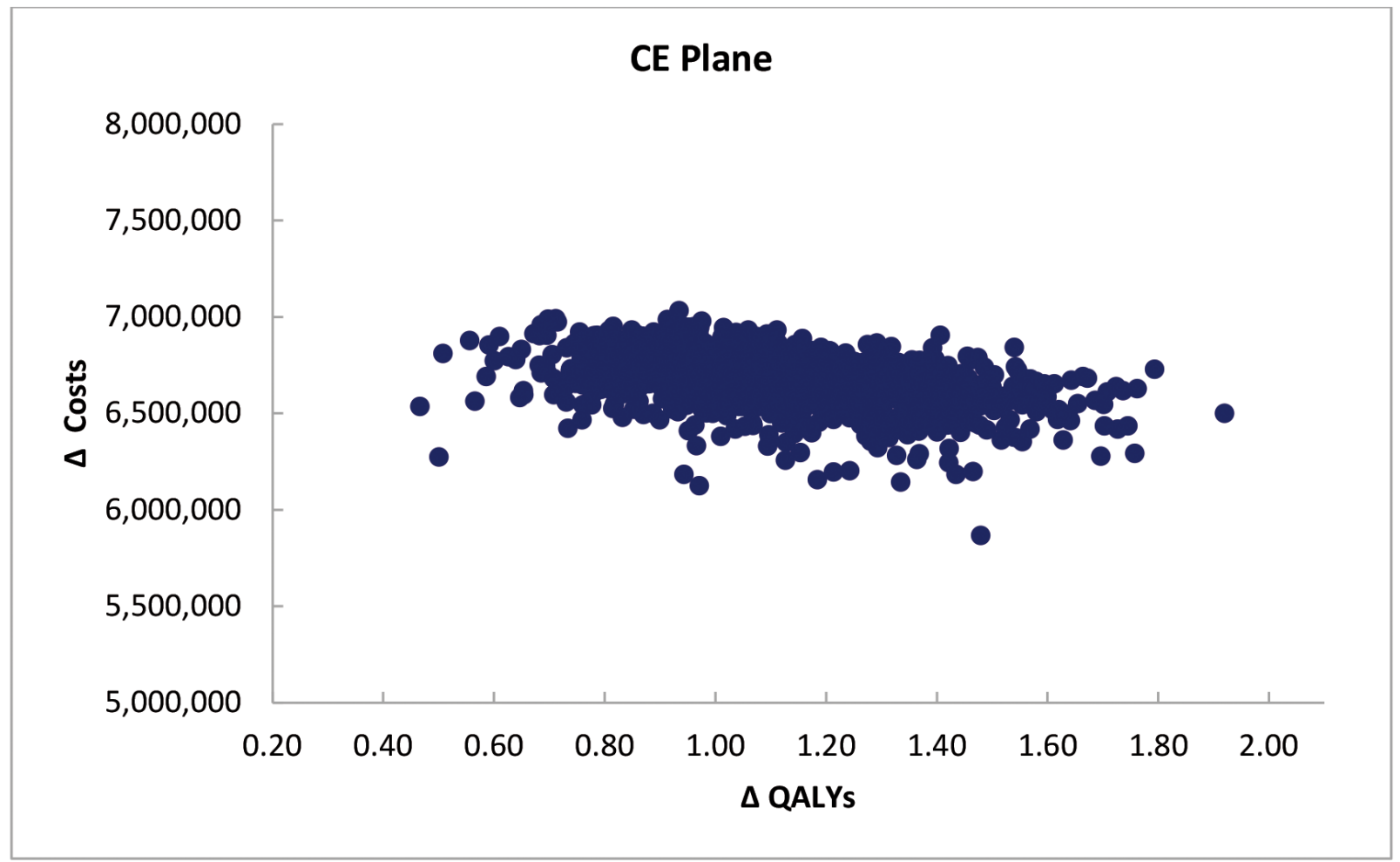

$\mathrm{CE}=$ cost effectiveness; QALY=quality-adjusted life year 
Figure 6. Cost-effectiveness Acceptability Curve in Treatment-naive Patients

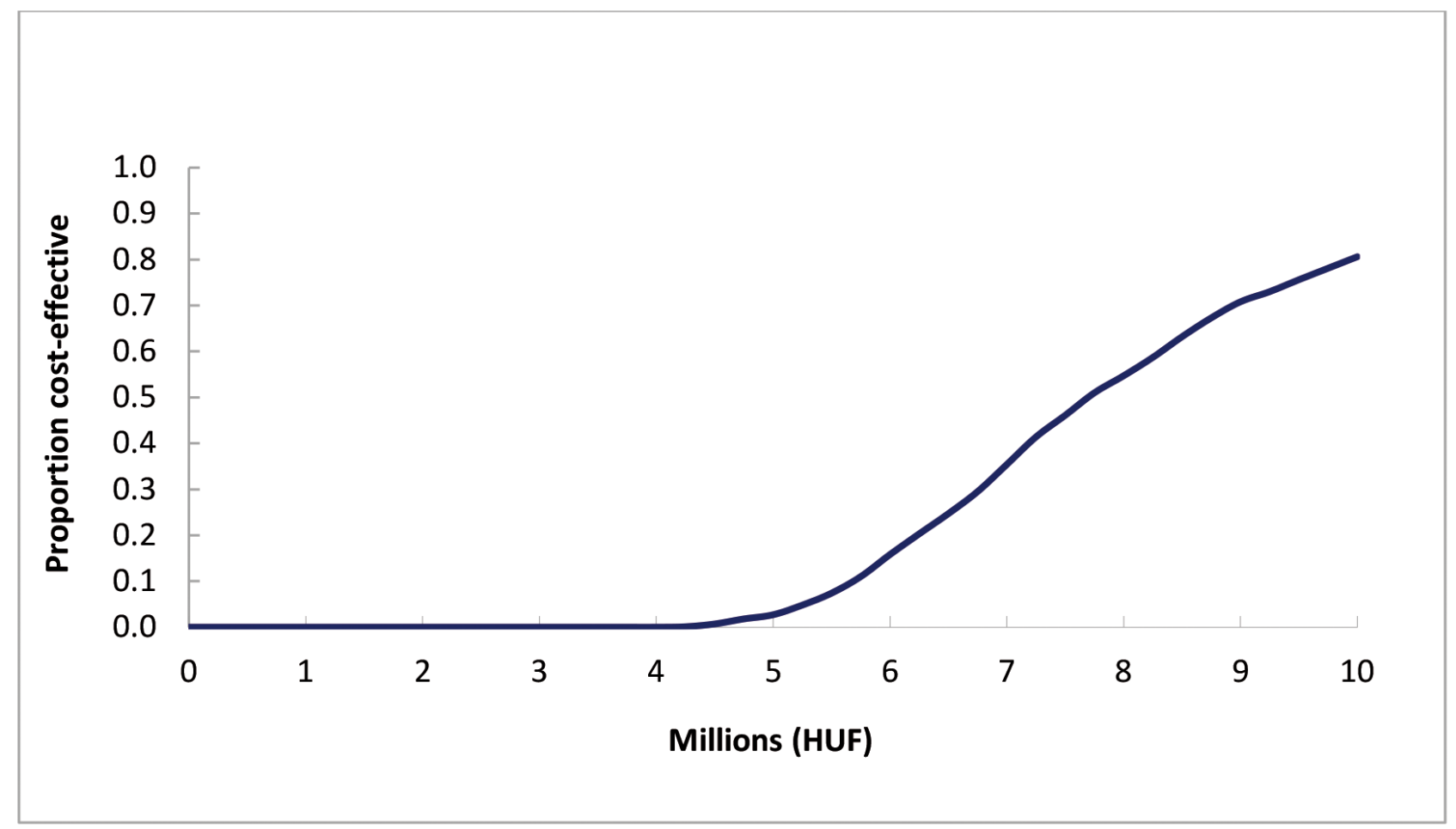

Figure 7. Cost-effectiveness Acceptability Curve in Treatment-experienced Patients

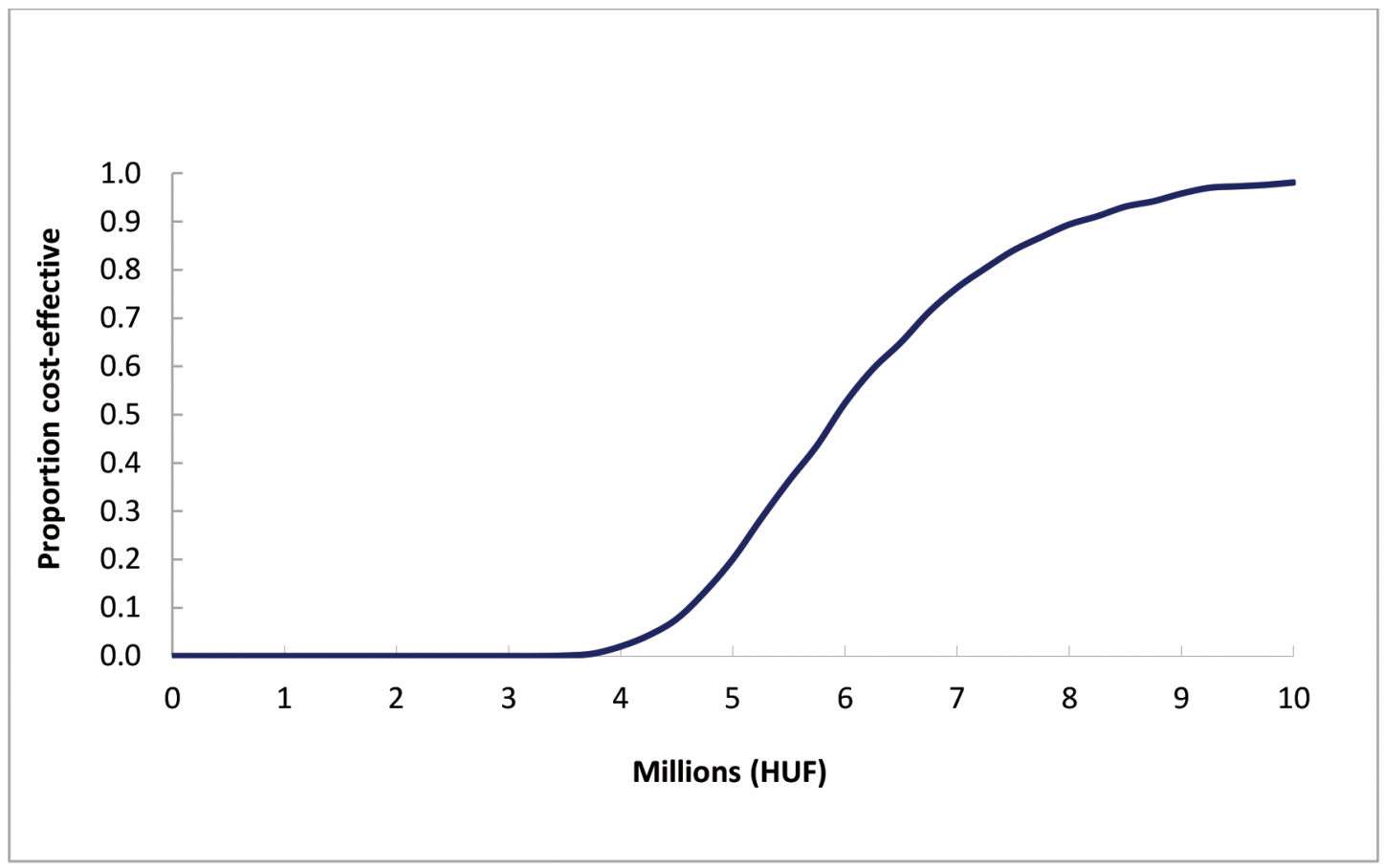

\section{DISCUSSION}

SPRINT- $2^{24}$ and the RESPOND-2 ${ }^{25}$ clinical trial results showed that boceprevir-based triple therapy provides significantly more effective treatment to patients with genotype-1 chronic HCV infection compared with current standard-of-care therapy. At the same time, the scarce resources require the payer to carefully evaluate the economic value of boceprevir when making decision on reimbursements. 
The aims of our study were to project lifetime clinical health benefits and estimate the cost-effectiveness of boceprevir-based strategies. The results of our model suggest that boceprevir in addition to peginterferon and ribavirin is projected to be a cost-effective treatment strategy compared with peginterferon plus ribavirin dual combination in both treatment-naive and treatment-experienced patients using a willingness-to-pay threshold of 8.46 million HUF. In the treatment-naive patients, the cost of the boceprevir-based strategies is lower than that in the treatment-experienced patients (HUF 4.56 million (€15,707) vs. HUF 6.66 million (€22,972). This can be explained by the significantly shorter duration of the therapy (28-week vs. 48-week) in non-cirrhotic treatment-naive patients with rapid virologic response. However, the higher additional cost in treatmentexperienced patients is counterweighed by the higher incremental health gains (QALYs) in the treatmentexperienced patients when compared to the treatment-naive patients. Consequently, boceprevir-based strategy resulted in lower ICER in treatment-experienced patients than in the treatment-naïve patients. The triple therapy is also projected to reduce lifetime incidence of serious liver disease-related complications such as DC, HCC and liver-related death both in the treatment-naive and treatment-experienced populations. Overall, the results demonstrate that adding boceprevir to peginterferon plus ribavirin provides substantial benefits in terms of value for money in both the treatment-naïve and treatment-experienced patients in the Hungarian setting.

Boceprevir remained cost-effective under a wide range of parameter values in the sensitivity analyses - both in treatment-naive and treatment-experienced patients in the Hungarian setting. The ICER values increased with the reduction of values of transition probabilities and/or incremental efficacy and utilities.

Sensitivity analysis was also performed on the base-case age of $\mathrm{HCV}$-infected population. Currently, the majority of the HCV infected patients in Hungary were infected with blood transfusions prior to $1992 .{ }^{11}$ However, the average age of treatment is shifting downward contributing a significant portion of new cases, ${ }^{8,12}$ the majority of whom are in their twenties or thirties. ${ }^{69}$ Currently the average age of patients with HCV infection is 48.1 years old. However, increasing numbers of intravenous drug users are expected to lower the average age of patients treated with HCV in the future. Therefore, younger cohort was tested in the sensitivity analysis. The results suggest that boceprevir is more beneficial (cost-effective) treatment strategy for the younger cohort of patients infected with HCV compared to the base-case population.

The launch of boceprevir is expected to reduce the burden of liver transplantations because of reduction in the incidence of advanced stage liver diseases. Annually, 40-50 liver transplantations are performed in Hungary. ${ }^{70-72}$ Expert estimations indicate 2-3 times more transplantations could be justified based on need. ${ }^{71,73}$ In 2012, Hungary joined EuroTransplant, an European non-profit organization responsible for encouraging and allocating organ transplants in its member countries. ${ }^{74,75}$ The membership is expected to expand access to liver donors and result in at least two times more liver transplantation. Consequently, the addition of boceprevir to standard therapy may become more favorable because of availability of more liver transplantations.

As with any mathematical model, our model has some assumptions and limitations. First, our model did not include the possibility of spontaneous HCV clearance, which can be observed in patients with mild states (F0 and F1) of HCV. This is similar to SVR called remission. However, likelihood of spontaneous remission in patients with chronic infection is very small; ${ }^{76-78}$ therefore, this health state was not included in the model. Second, we assumed that patients who achieved SVR were not at risk for reactivation of HCV infection. Longterm outcomes of several studies ${ }^{79-84}$ in $\mathrm{HCV}$ infection show that more than $90 \%$ of patients who achieved SVR remained virus-free during long-term follow-up.

However, in sensitivity analysis, cirrhotic patients were examined to have an excess risk of developing DC and HCC, even if they achieved SVR. ${ }^{85}$ Third, patients with compensated cirrhosis were assumed to have the same 
mortality risk as the general population. The sensitivity analysis showed that increasing the mortality risk of patients with compensated cirrhosis improves the cost-effectiveness ratio.

\section{CONCLUSION}

The addition of boceprevir to the standard therapy (pegylated interferon plus ribavirin) regimen is projected to substantially reduce the burden of HCV-related liver complications. In addition, the boceprevir-based therapy is projected to be cost-effective when compared to the standard therapy in both treatment-naive and in treatment-experienced patients with chronic HCV infection in Hungary.

\section{CONFLICT OF INTEREST DECLARATION}

Jagpreet Chhatwal, Assistant Professor at the University of Pittsburgh, made a part of his contribution to the model development and manuscript while employed at Merck, Sharp \& Dohme Corporation. Jagpreet Chhatwal's effort was supported by the National Center For Advancing Translational Sciences of the National Institutes of Health under Award Number KL2TR000146. The content is solely the responsibility of the authors and does not necessarily represent the official views of the National Institutes of Health. Antoine El Khoury was employed by Merck, Sharp \& Dohme Corporation at the time the study was conducted.

\section{REFERENCES}

${ }^{1}$ Dienstag JL, McHutchinson JG: American Gastroenterological Association medical position statement on the management of hepatitis C. Gastroenterology. 2006;130(1):225-30.

2 Ghany MG, Strader DB, Thomas DL et al. Diagnosis, management, and treatment of hepatitis C: an update. Hepatology. 2009;49(4):1335-74.

3 World Health Organization: Hepatitis C, Fact sheet No.164. http://www.who.int/mediacentre/factsheets/ fs164/en/index.html. Accessed October 19, 2011.

${ }^{4}$ El Khoury AC, Klimack WK, Wallace C, et al. Economic burden of hepatitis C-associated diseases in the United States. J Viral Hepat. 2012;19:153-60.

5 El Khoury AC, Wallace C, Klimack WK, et al Economic burden of hepatitis C-associated diseases: Europe, Asia Pacific, and the Americas. J Med Econ. 2012;15(5):8877-96.

${ }^{6}$ World Hepatitis Alliance: World Hepatitis Day. http:/ / www.worldhepatitisalliance.org/worldhepatitisday2011. aspx. Accessed November 2, 2011.

7 European Parlament: Written Declaration on hepatitis C, 2007. http://www.europarl.europa.eu/sides/ getDoc.do?reference=P6_TA(2007)0102\&language=EN. Accessed February 20, 2012.

8 Országos Egészségbiztosítási Pénztár - Elemzési, Orvosszakértői és Szakmai Ellenőrzési Főosztály: Hepatitis C virus okozta krónikus májgyulladás diagnosztikája és terápiájának finanszírozási protokollja. http://site. oep.hu/steam/downloads/finprot/17_Hepatitis_C_finanszirozasi_protokollja.pdf. Accessed September $13,2011$.

${ }^{9}$ McHutchinson JG, Bacon BR: Chronic hepatitis C: an age wave of disease burden. Am J Manag Care. 2005;11(10 Supp):S286-95.

${ }^{10}$ Országos Egészségbiztosítási Pénztár; Hatályos finanszírozási Protokollok: Hepatitis C vírus okozta krónikus májgyulladás diagnosztikája és terápiájának finanszírozási protokollja. http://www.oep.hu/portal/page?_ pageid=35,31793613\&_dad=portal\&_schema=PORTAL>. Accessed May 16, 2011. 
${ }^{11}$ Dr.Dósa Ágnes: A hepatitis C-fertőzés miatt megítélt kártérítés. LAM 2003;13(3):244-5.

${ }^{12}$ Makara Mihály: Lappangó vírusok, panaszmentes májbetegek. MedicalOnline, Professional Publishing. http://www.medicalonline.hu/cikk/lappango_virusok_panaszmentes_majbetegek; 2011. Accessed March 17, 2012.

${ }^{13}$ Wilkins T, Malcolm JK, Raina D. et alHepatitis C: diagnosis and treatmnet. Am Fam Physician. 2010;81(11):13517.

${ }^{14} \mathrm{Yu}$ JW, Sun LJ, Kang B, et al. Efficacy and factors influencing treatment with peginterferon alpha-2a and ribavirin in elderly patients with chronic hepatitis C. Hepatobiliary Pancreat Dis Int. 2012;11(2):185-92.

${ }^{15}$ McHutchison J Lawitz EJ, Shiffman ML, et al. Peginterferon alfa-2b or alfa-2a with ribavirin for treatmnet of hepatitis c infection. N Engl J Med 2009;361:580-93.

${ }^{16}$ Poynard T, Colombo M, Bruix J, et al. Peginterferon alfa-2b and ribavirin: effective in patients with hepatitis C who failed interferon alfa/ribavirin therapy. Gastroenterology 2009;136:1618-8.

${ }^{17}$ De Bruijne J, Buster EHCJ, Gelderblom HC, et al. Treatmnet of chronic hepatitis C virus infection - Dutch national guidelines. Neth J Med. 2008;66(7):311-22.

${ }^{18}$ Alsio A, Rembeck K, Askarieh G, et al. Impact of obesity on the bioavailability of peginterferon- $\alpha 2 \mathrm{a}$ and ribavirin and treatmnet outcome for chronic hepatitis C genotype 2 or 3. PLoS ONE. 7(5):e37521. doi:10.1371/ journal.pone.0037521

${ }^{19}$ Charlton MR, Pockros PJ, Harrison SA: Impact of obesity on treatment of chronic hepatitis C. Hepatology 2006;43:1177-86.

${ }^{20}$ Hagymási K, Fehér J: A testsúlycsökkentés hatása a kombinált interferon-alfa-2a + ribavirin kezelésre adott válaszra idült HCV-hepatitiszben. Orv Hetil 2008;149(46):2189-92.

${ }^{21}$ McHutchison J, Lawitz EJ, Shiffman ML et al. Peginterferon alfa-2b or alfa 2a with ribavirin treatment of hepatitis C infection. N Engl J Med 2009;361:580-93.

${ }^{22}$ Poynard T, Colombo M, Bruix J, et al. Peginterferon alfa-2b and ribavirin: effective in patients with hepatitis C who failed interferon alfa/ribavirin therapy. Gastroenterology 2009;136:1618-28.

${ }^{23}$ European Commission. Community Register of medicinal products. http:/ / ec.europa.eu/health/documents / community-register/html/alfregister.htm. Accessed May 15, 2012.

${ }^{24}$ Poordad F, McCone J, Bacon BR, et al. Boceprevir for untreated chronic HCV genotype 1 infection. N Engl J Med 2011;364:1195-206.

${ }^{25}$ Bacon BR, Gordon SC, Lawitz E, et al. Boceprevir for previously treated chronic HCV genotype 1 infection. N Engl J Med 2011;364:1207-17.

${ }^{26}$ European Public Assessment Reports: Victrelis. European Medicines Agency. http://www.emea.europa.eu/ ema/index.jsp?curl=pages\%2Fmedicines\%2Flanding\%2Fepar_search. Accessed April 11, 2012.

${ }^{27}$ Sullivan SD, Craxi A, Albertiy A, et al. Cost effectiveness of peginterferon $\alpha$-2a plus ribavirin versus interferon $\alpha$-2b plus ribavirin as initial therapy for treatment naive chronic hepatitis C. Pharmacoeconomics 2004;22(4):257265.

${ }^{28}$ Younossi ZM, Singer ME, McHutchison JG, et al. Cost effectiveness of interferon $\alpha 2 \mathrm{~b}$ combined with ribavirin for the treatment of chronic hepatitis C. Hepatology 1999;30:1318-24.

${ }^{29}$ Salomon JA, Weinstein MC, Hammitt JK, et al. Cost-effectiveness of treatment for chronic hepatitis C infection in an evolving patient population. JAMA. 2003;290:228-37. 
${ }^{30}$ Siebert U, Sroczynski G, Aidelsburger P, et al. Clinical effectiveness and cost effectiveness of tailoring chronic hepatitis $\mathrm{C}$ treatment with peginterferon alpha- $2 \mathrm{~b}$ plus ribavirin to $\mathrm{HCV}$ genotype and early viral response. A decision analysis based on German guidelines. Pharmacoeconomics 2009;27(4):341-54.

${ }^{31}$ Population Census 2011: Questions on private individuals, Census topics. http://www.nepszamlalas.hu/ index.php?menu=1279\&langcode=en. Accessed June 21, 2012.

${ }^{32}$ National Central Statistical Office. 'Persons naturalised in Hungary' and 'Foreign citizens reside in Hungary', International migration. http://statinfo.ksh.hu/Statinfo/themeSelector.jsp?page $=2 \& s z s t=W N V N$. Accessed June 21, 2012.

${ }^{33}$ Országos Egészségbiztosítási Pénztár: Kijelölt intézmények listája. http://www.oep.hu/portal/page?_ pageid=35,21339700\&_dad=portal\&_schema=PORTAL. Accessed June 8, 2012.

${ }^{34}$ Thein HH, Yi Q, Dore GJ, et al. Estimation of stage specific fibrosis progression rates in chronic hepatitis C virus infection: A meta analysis and meta regression. Hepatology. 2008;48(2):418-31.

${ }^{35}$ Yoshida H, Shiratori Y, Moriyama M, et al: Interferon therapy reduces the risk for hepatocellular carcinoma: national surveillance program of cirrhotic and noncirrhotic patients with chronic hepatitis $\mathrm{C}$ in Japan. Ann Intern Med. 1999;131:174-81.

${ }^{36}$ Tateyama M, Yatsuhashi $\mathrm{H}$, Taura $\mathrm{N}$ et al: Alpha-fetoprotein above normal levels as a risk factor for the development of hepatocellular carcinoma in patients infected with hepatitis C virus. J Gastroenterol 2011;46:92100.

${ }^{37}$ Miura Y, Shibuya A, Adachi S, et al: Occult hepatitis B virus infection as a risk factor for hepatocellular carcinoma in patients with chronic hepatitis $C$ in whom viral eradication fails. Hepatol Res 2008;38(6):546-56.

${ }^{38}$ Fattovich, G, Giustina G, Degos F, et al. Morbidity and mortality in compensated cirrhosis type C: a retrospective follow-up study of 384 patients. Gastroenterology 1997;112(2):463-72.

${ }^{39}$ Benvegnu L, Noventa F, Bernardinello E, et al. Evidence for an association between the aetiology of cirrhosis and pattern of hepatocellular carcinoma development. Gut 2011;48:110.

${ }^{40}$ Gentilini P, Laffi G, La Villa G, et al. Long course and prognostic factors of virus-induced cirrhosis of the liver. Am J Gastroenterol 1997;92:66-72.

${ }^{41}$ Sangiovanni A, Prati GM, Fasani P, et al. The natural history of compensated cirrhosis due to hepatitis C virus: A 17 year cohort study of 214 patients. Hepatology 2006;43:1303-10.

${ }^{42}$ Serfaty L et al: Determinants of outcome of compensated hepatitis C virus-related cirrhosis. Hepatolology 1998;27:1435-40.

${ }^{43}$ Bruno S, Silini E, Crosignani A, et al. Hepatitis C virus genotypes and risk of hepatocellular carcinoma in cirrhosis: a prospective study. Hepatology 1997;25:754-8.

${ }^{44}$ Tsukuma H, Hiyama T, Tanaka S, et al. Risk factors for hepatocellular carcinoma among patients with chronic liver disease. N Engl J Med 1993;328:1797.

${ }^{45}$ Planas R, Balleste B, Alvarez MA, et al: Natural history of decompensated hepatitis C virus-related cirrhosis. A study of 200 patients. J Hepatol 2004;40(5):823-30

${ }^{46}$ National Health Insurance Fund. Database research and analysis, Feb - June 2011.

${ }^{47}$ Hungarian Life Table 2003. Központi Statisztikai Hivatal, 2004. http://www.lifetable.de/cgi-bin/Country. plx?Country=Hungary. Accessed July 26, 2011.

${ }^{48}$ Wolfe R, Roys E, Merion R: Trends in Organ donation and transplantation in the United States, 1999-2008. Am J Transplantation. 2010;10(4p2):961-72. 
${ }^{49}$ D'Amico G, Morabito A, Pagliaro L, et al. Survival and prognostic indicators in compensated and decompensated cirrhosis. Dig Dis Sci 1986;31:468-75.

${ }^{50}$ Salerno F, Borroni G, Moser P, et al. Survival and prognostic factors of cirrhotic patients with ascites: a study of 134 outpatients. Am J Gastroenterol 1993;88:514-9.

${ }^{51}$ Chong CAKY, Gulamhussein A, Heathcote EJ, et al. Health-state utilities and quality of life in hepatitis C patients. Am J Gastroenterol. 2003;98(3):630-8.

${ }^{52}$ Wright M, Grieve R, Roberts J, et al. Health benefits of antiviral therapy for mild chronic hepatitis C: randomised controlled trial and economic evaluation. Health Technology Assessment. 2006;10(21):1-130.

${ }^{53}$ Wilson J, Yao GL, Raftery J, et al. A systematic review and economic evaluation of epoetin alfa, epoetin beta and darbepoetin alfa in anaemia associated with cancer, especially that attributable to cancer treatment. Health Technology Assessment. http://www.hta.ac.uk/execsumm/summ1113.htm. Accessed September 3, 2011.

${ }^{54}$ Wong JB, Bennett WG, Koff RS, et al. Pretreatmnet evaluation of chronic hepatitis C: Risks, benefits, and costs. JAMA 1998;280:2088-93.

${ }^{55}$ Gaál P: Health care systems in transition: Hungary. Copenhagen, WHO Regional Office for Europe on behalf of the European Observatory on Health Systems and Policies, 2004. http://www.euro.who.int/_ data/assets/pdf_file/0008/80783/E84926.pdf. Accessed June 6, 2012.

${ }^{56}$ Makara M, Horvath G, Gervain J, et al. Ajánlás a B-, a C- és a D-vírus hepatitisek diagnosztikájára és antivirális kezelésére. Orv Hetil. 2012;153:375-94.

${ }^{57}$ Poordad F, Lawitz EJ, Reddy KR, et al. A randomized trial comapring ribavirin dose reduction versus erythropoietin for anemia management in previously untreated patients with chronic hepatitis $\mathrm{C}$ receiving boceprevir plus peginterferon/ribavirin. Presented at the 47th Annual Meeting of the European Association for the Study of the Liver, April 18-22, 2012, Barcelona, Spain.

${ }^{58}$ World Health Organization - Choosing Intervetions that are Cost Effective (WHO-CHOICE): 'Costeffectiveness thresholds'. http://www.who.int/choice/costs/CER_thresholds/en/index.html. Accessed September 26, 2011.

${ }^{59}$ Központi Statisztikai Hivatal (KSH): Bruttó hazai termék (GDP) végső felhasználás folyó áron’ és ‘Népesség, Népmozgalom. http://portal.ksh.hu/pls/ksh/docs/hun/xsadat_eves/i_wnt001b.html. Accessed September 26, 2011.

${ }^{60}$ Az Egészségügyi Minisztérium szakmai irányelve - az egészség-gazdaságtani elemzések készítéséhez. http:// www.eum.hu/egeszsegpolitika/minosegfejlesztes/modszertani-segedanyagok. Accessed March 19, 2012.

${ }^{61}$ Belgian Health care Knowledge Center (KCE). Guidelines for pharmacoeconomic evaluations in Belgium (2008). https://kce.fgov.be/sites/default/files/pag_documents/d20081027327.pdf. Accessed April 18, 2012.

${ }^{62}$ Institute für Qualitat und Wirtschaftlichkeit im Gesundheitswesen (IQWIG). General methods for the assessment of the relations of benefits to costs. https://www.iqwig.de/download/General_Methods_for_ the_Assessment_of_the_Relation_of_Benefits_to_Costs.pdf. Accessed April 17, 2012.

${ }^{63}$ National Institute for Clinical Excellence (NICE). Guide to the methods of technology appraisals (2008). http://www.nice.org.uk/aboutnice/howwework/devnicetech/technologyappraisalprocessguides/?domedia =1\&mid=B52851A3-19B9-E0B5-D48284D172BD8459. Accessed April 18, 2012.

${ }^{64}$ Agencja Oceny Technologii Medycznych (AOTM). Guidelines for conducting Health Technology Assessment (2009). http://www.aotm.gov.pl/index.php?id=401. Accessed April 18, 2012.

${ }^{65}$ General guidelines for economic evaluations from the Pharmaceutical Benefits Board (2003). http://www.tlv. se/in-english-old/medicines-new/pricing-and-reimbursement-of-medicines/. Accessed April 18, 2012. 
${ }^{66}$ Guidance to manufactureres for completition of new product assessment form (2007), Scottish Medicines Consortium. http://www.scottishmedicines.org.uk/Submission_Process/Submission_Guidance_and_ Templates_for_Industry/Templates-Guidance-for-Submission/Templates-Guidance-for-Submission. Accessed April 18, 2012.

${ }^{67}$ Instituto Nacional da Farmácia e do Medicamento. Guidelines for Economic Drug Evaluation Studies. http://www.infarmed.pt/portal/page/portal/INFARMED/ENGLISH/PCAEC04_vering.pdf. Accessed April 18, 2012.

${ }^{68}$ College des Economistes de la Santé (CES). French guidelines for the economic evaluation of health care technologies (2004). http://www.ces-asso.org/docs/France_Guidelines_HE_Evaluation.PDF. Accessed April 18, 2012.

${ }^{69}$ Rácz J és Ritter I: Az injekciós droghasználat felmérése agyors helyzetfelmérés és válasz (RAR) módszerével Magyarországon. Addiktológia (Addictologia Hungarica). 2003;3-4:305-45

${ }^{70}$ Országos Vérellátó Szolgálat: Transzplantációs koordinátori hálózat bővítése Magyarországon, Szervdonációs Minőségbiztosítási Program (egy éves pilot). 2011. http://www.ovsz.hu/sites/ovsz.hu/files/ szervadomanyozas_dokumentum/2011-08-02-hatteranyag.pdf. Accessed July 10, 2012.

${ }^{71}$ Nemzeti Erőforrás Minisztérium: Idén mintegy 350 szervátültetés történt. http://www.eum.hu/archivum/ hirek/iden-mintegy-350. Accessed June 10, 2012.

${ }^{72}$ Donor Info: Májátültetés. http://dnr.hu/tetudod/atultetes_beultetes_donacio_transzplantacio/majatultetes_ majtranszplantacio/. Accessed July 6, 2012.

${ }^{73}$ Gerlei Zsuzsa: Májtranszplantáció felnôttkorban. Kinek indokolt, és hogyan juthat hozzá Magyarországon? LAM 2008;18(1):43-5.

${ }^{74}$ EuroTransplant International Foundation. http://www.eurotransplant.org/cms/index.php?page=home. Accessed July 10, 2012.

${ }^{75}$ Eurotransplant. Eurotransplant starts cooperation with Hungary, http://www.eurotransplant.org/cms/ index.php?page $=$ newsitems\&action $=$ viewitem\&oid=458\&id=1696. Accessed July 11, 2012.

${ }^{76}$ Raghuraman S, Park H, Osburn WO, et al. Spontaneous clearance of chronic hepatitis C virus infection is associated with apperance of neutraliting antibodies and reversal of T-cell exhaustion. J Infect Dis 2012;205:76371.

${ }^{77}$ Watanabe H, Saito T, Shinzawa H, et al. Spontaneous elimination of serum hepatitis C virus (HCV) RNA in chronic HCV carriers: A population-based cohort study. J Med Virol 2003;71:56-61.

${ }^{78}$ Scott JD, McMahon J, Bruden D, et al. High rate of spontaneous negativity for hepatitis C virus RNA after establishment of chronic infection in Alaska Natives. Clin Infect Dis 2006;42:945-52

${ }^{79}$ Trapero-Marugán M, Mendoza J, Chaparro M, et al. Lond-term outcome of chronic hepatitis C patients with sustained virological response to peginterferon plus ribavirin. World J Gastroenterol 2011;17(4):493-8.

${ }^{80}$ Reichard O, Glaumann H, Frydén A, et al. Long-term follow-up of chronic hepatitis C patients with sustained virological response to alpha-interferon. J Hepatology 1999;30:783-7.

${ }^{81}$ George S, Bacon B, Brunt E, et al: Clinical, virologic, histologic, and biochemical outcomes after successful HCV therapy: A 5-year follow-up of 150 patients. Hepatology 2009;49:729-38.

${ }^{82}$ Swain MG, Lai MY, Shiffman ML, et al: A sustained virologic response is durable in patients with chronic hepatitis C treated with peginterferon alfa-2a and ribavirin. Gastroenterology 2010;139:1593-601. 
${ }^{83}$ Desmond CP, Roberts SK, Dudley F, et al: Sustained virological response rates and durability of the response to interferon-based therapies in hepatitis C patients treated in the clinical setting. J Viral Hepatitis. 2006;13:3115.

${ }^{84}$ Lau DTY, Kleiner DE, Ghany MG, et al: 10-year follow-up after interferon- $\alpha$ therapy for chronic hepatitis C. Hepatology 1998;28:1121-7.

${ }^{85}$ Cardoso AC, Moucari1 R, Figueiredo-Mende C, et al: Impact of peginterferon and ribavirin therapy on hepatocellular carcinoma: incidence and survival in hepatitis $\mathrm{C}$ patients with advanced fibrosis. $J$ Hepatol 2010;52:652-7.

${ }^{86}$ Fleming KM, Aithal GP, Card TR, West J: All-cause mortality in people with cirrhosis compared with the general population: a population-based cohort study. Liver Int 2012;32(1):79-84. 